\title{
A New Mapania Species (Cyperaceae) from Sarawak, Malaysia
}

\author{
ZINNIRAH SHABDIN*, MEEKIONG KALU* \& MIRAADILA MOHD ISA \\ Department of Plant Science and Environmental Ecology, Faculty of Resource Science and Technology, \\ Universiti Malaysia Sarawak, 94300 Kota Samarahan, Sarawak
}

\begin{abstract}
Mapania kadimiana Shabdin, Meekiong \& Miraadila, a new species from Sarikei Division, Sarawak is described and illustrated. It possesses distinctly 3-ranked leaves with tightly imbricated leaf sheaths and distinctly dark chocolate brown which closely similar to $M$. spadicea Uittien. The new species however, is different by having 1-4 spikes in sessile terminal capitulum whereas $M$. spadicea always has solitary spikes. $M$. kadimiana occurs lithophytically on rock surface or in damp or wet places on slopes near streams. Recognition of M. kadimiana increased the total number of Mapania in Sarawak to 32 species.
\end{abstract}

Keywords: Borneo, conservation, Cyperaceae, Mapanioideae, taxonomy

\section{INTRODUCTION}

The family Cyperaceae currently comprises two subfamilies, Mapanioideae (11 genera, 165 species) and Cyperoideae (95 genera, 5238 species) (Govaerts et al., 2007; Muasya et al., 2009). The subfamily Mapanoideae possesses a particular specialization in the inflorescence structure termed as 'spicoid' which differentiates from the subfamily Cyperoideae. Three tribes are recognised within Mapanioideae namely Hypolytreae, Chrysitricheae and Chritricheae (Simpson et al., 2003; Muasya et al., 2009). The genus Mapania is placed in the tribe Hypolytreae and is being divided into five sections based on their geographical distribution. The sections are Mapania, Thoracostachyum, Pandanophyllum, Pycnocephala and Mapaniopsis (Simpson, 1992 \& 1996) and comprising a total of 84 species (Govaerts et al., 2007). The number however has increased as several new species been discovered recently, particularly from Malesian region i.e. Shabdin et al. (2013a \& 2013b), and Miraadila and Shabdin (2016). Mapania section Pandanophyllum is endemic to Asia, Indomalesia, Australia and the Pacific Islands. Section Thoracostachyum is also generally restricted to these areas, but two species occur in the Seychelles (Simpson, 1992).

\section{MATERIALS AND METHODS}

Botanical collections were conducted from April to December 2014 which covers various localities from western to eastern parts of Sarawak. Sample collections and herbarium specimens' preparation were made accordingly to the standard Herbarium Specimen Collection (Bridson \& Forman, 1992). Samples identification and verification were conducted at the Herbarium of Sarawak Forest Department (SAR) and Herbarium of Universiti Malaysia Sarawak.

\section{Species Description}

Mapania kadimiana Shabdin, Meekiong \& Miraadila sp. nov. (Figure 1-3).

Diagnosis: Mapania kadimiana closely resembles $M$. spadicea Uittien differing by having three spikes in sessile terminal capitulum (vs solitary spikes not forming a capitulum).

Type: MALAYSIA, Borneo, Sarawak, Sarikei Division, Sebangkoi Recreation Park, 18 December 2014, Miraadila, M.I., Baharuddin \& Meekiong, K., MY 0036 (Holotype: SAR, isotype: Herbarium of Universiti Malaysia Sarawak \& SAN). 


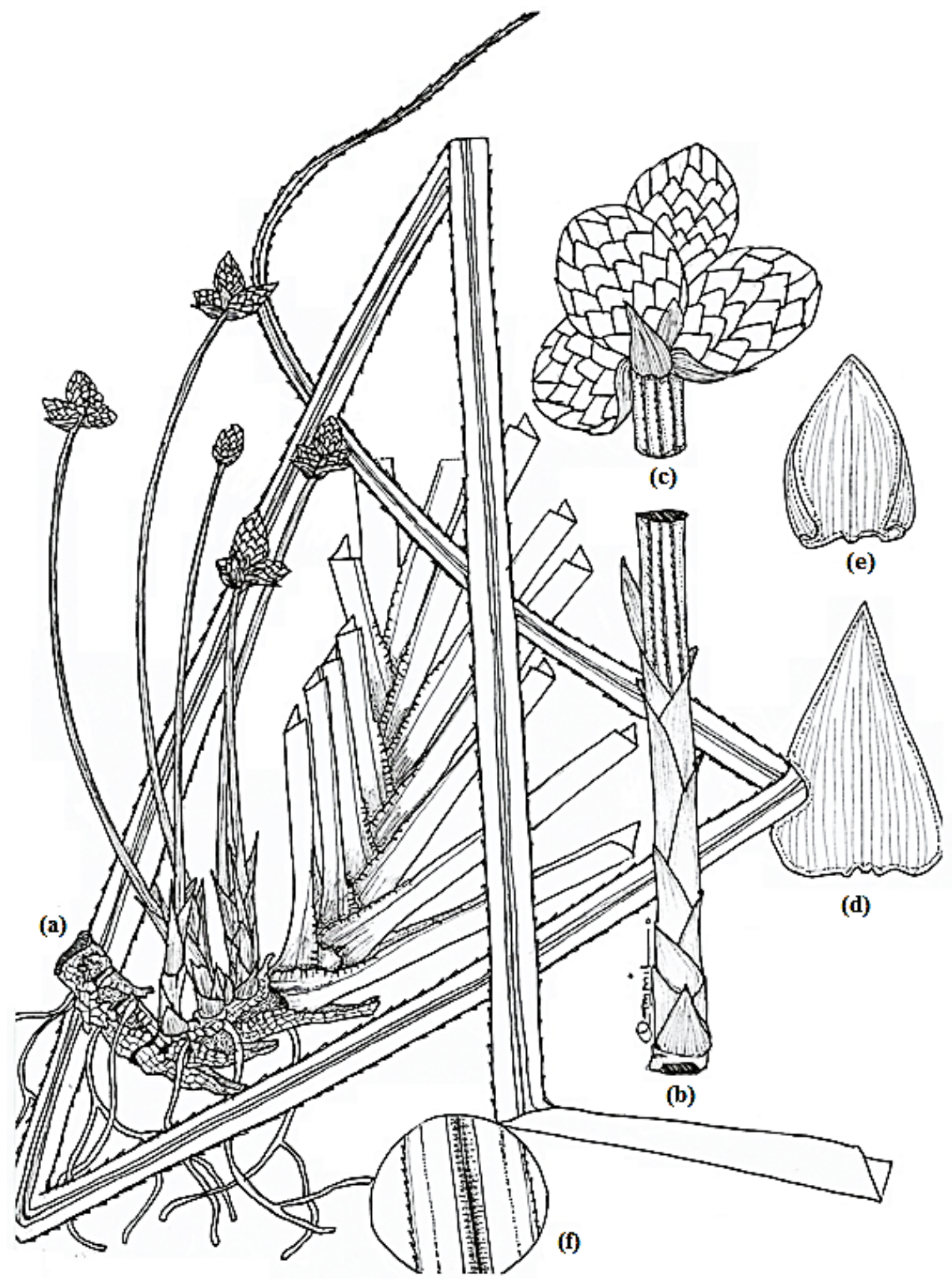

Figure 1. Mapania kadimiana Meekiong, Shabdin \& Miraadila, sp. nov. (a) Plant with solitary culm and inflorescences, (b) Inflorescence peduncle with involucral bracts, (c) Inflorescence, (d) Spicoid bract, (e) Floral bract, (f) Leaf midrib - Drawing by Meekiong Kalu based on type specimen MY 0036 (SAR). 

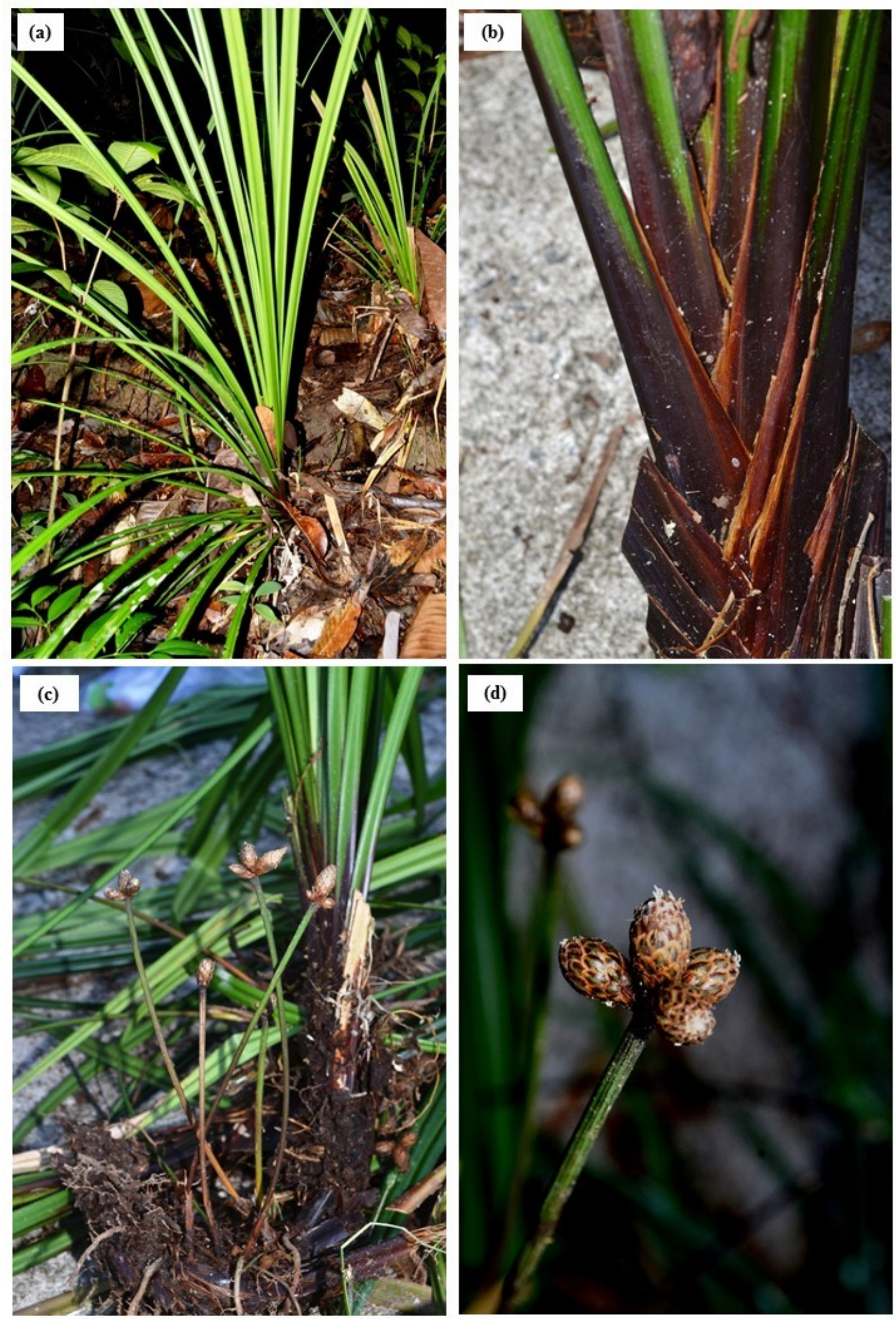

(d)

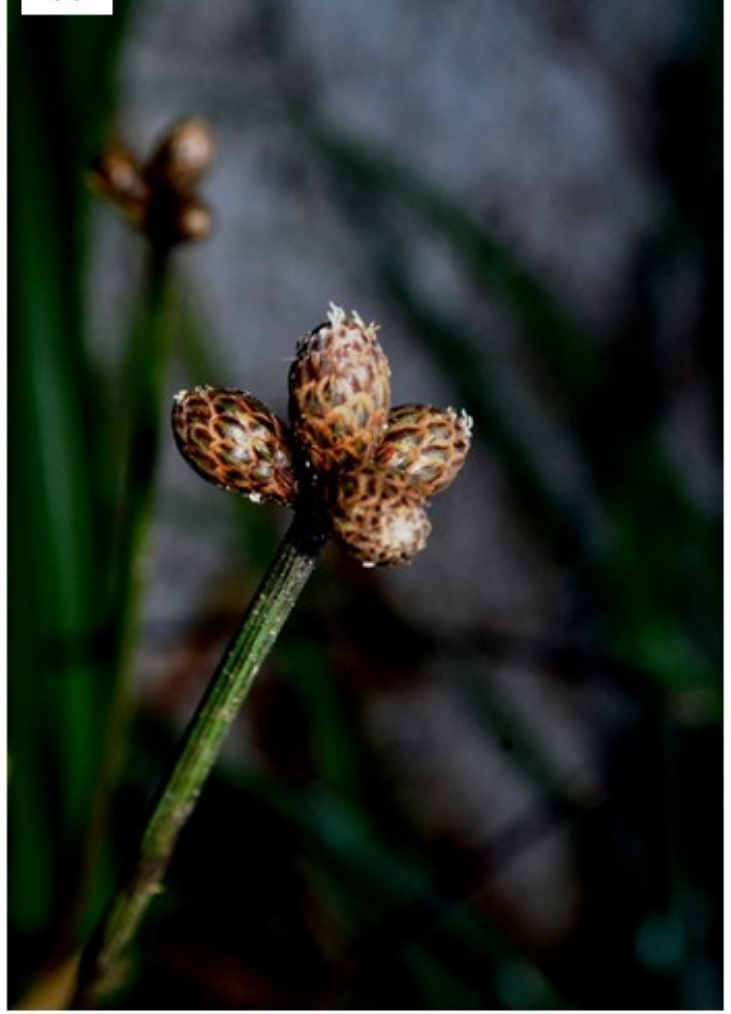

Figure 2. Mapania kadimiana Shabdin, Meekiong \& Miraadila, sp. nov. (a) plant habit in natural habitat, (b) lower part of the plant showing sheaths dark chocolate brown, (c) inflorescence erect from the rhizome, (d) inflorescence, spikes forming a sessile terminal capitulum. 

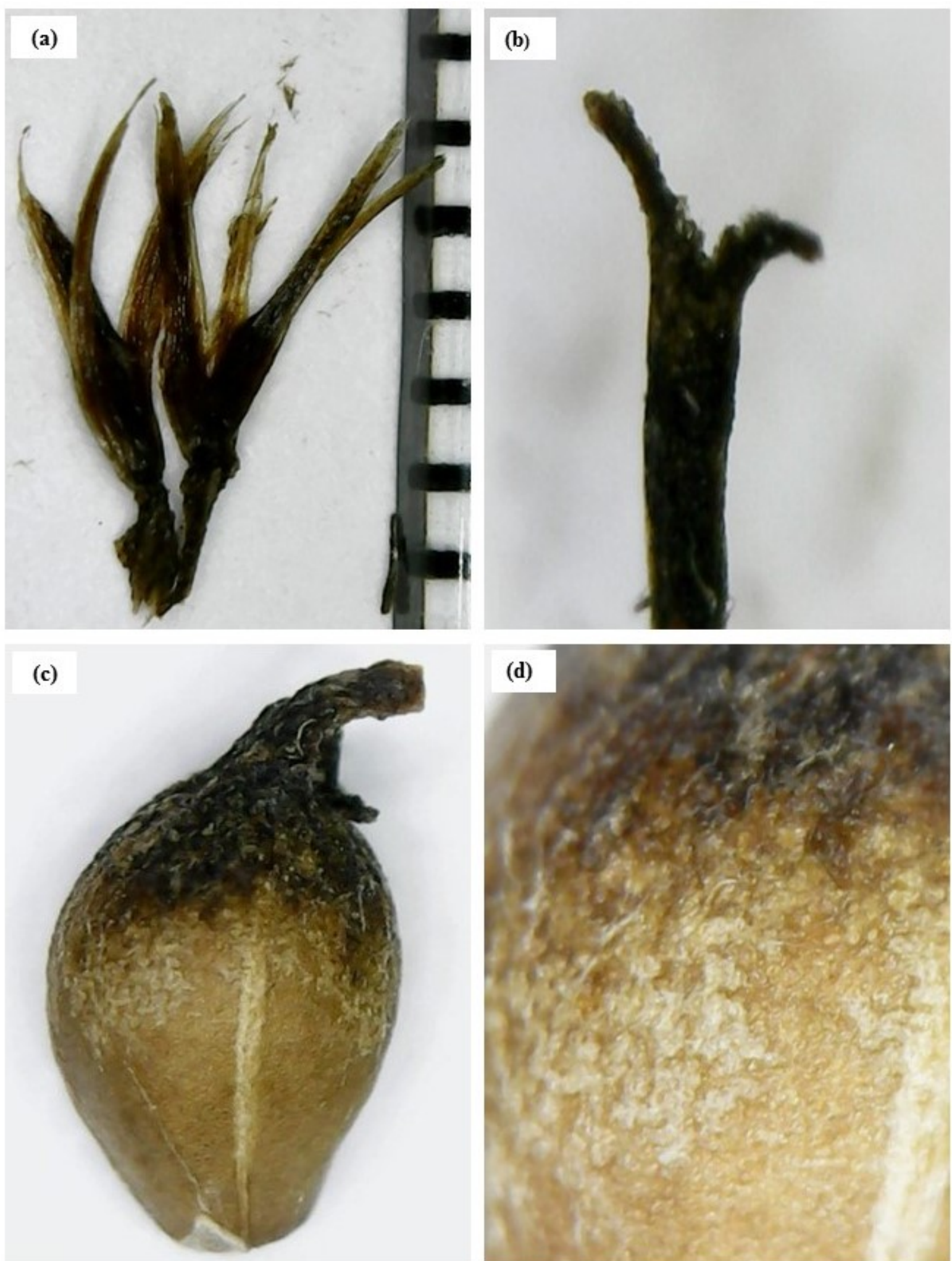

(d)

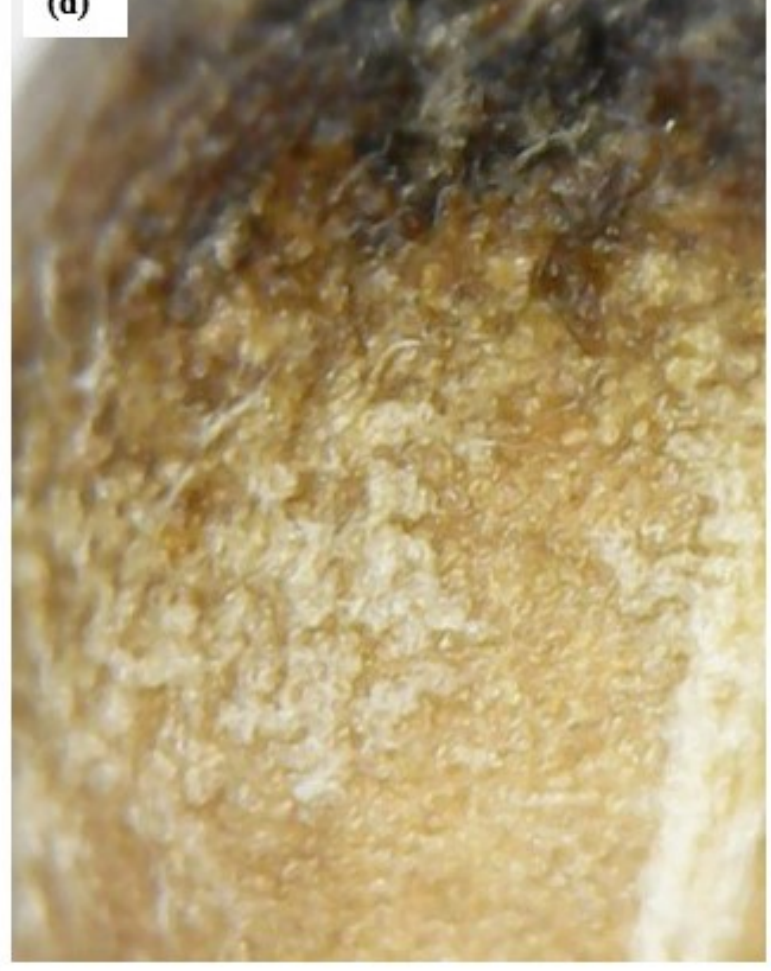

Figure 3. Mapania kadimiana Shabdin, Meekiong \& Miraadila, sp. nov. (a) spicoids, (b) stigma, 2 branch, (c) fruit, with keeled apex, (d) fruit surface, with small tubercles. 
Ecology \& distribution: At present this species is recorded from the type locality only where it occurs lithophytically or on slopes in wet or damp places, often near to streams under mixed dipterocarp forest.

Description: Robust, rhizomatous; rhizome 13-15 mm diameter. Culm solitary, more or less erect or lateral, 5-27 x $0.5-0.9 \mathrm{~cm}$, terete, mostly scabrid, medium greenish when fresh and becoming brownish when dry. Leaves basal, crowded and distinctly 3-ranked, up to $155 \mathrm{~cm}$ long; leaf blade narrowly linear, 122$145 \times 2-2.5 \mathrm{~cm}$, apex gradually narrowed, acuminate with long acumen, 8-10 cm long, base very gradually narrowed into sheath, coriaceous, medium green when fresh and becoming brownish when dry 1-nerved to indistinctly 3-nerved, secondary nerves indistinct with septate-nodulose when dry, strongly inverse $\mathrm{w}$-shaped in cross-section, margins densely serrulate, pseudopetiole absent, sheaths lanceolate, $6.2-10 \times 1-2 \mathrm{~cm}$, apex very gradually narrowed, thickly coriaceous, shiny, mid- to -dark chocolate brown. Involucral bract 2-4, glumaceous, lanceolate, 20-24 x 3-5 mm, apex acuminate, dark chocolate brown. Inflorescence up to 10 or more per plant, terminal capitulum, composed of 3 spikes, seldom with solitary spike; spikes rounded to lanceolate, $10-20 \times 5-8 \mathrm{~mm}$, acute to obtuse, or sub-obtuse, greenish brown; spicoid bract lanceolate, 5-8 x 6-8 mm, subobtuse, subcoriacoues, greenish brown, light brown along the margin edge, faintly with hairs, nerves indistinct; floral bract 6 , free, lower 2 bracts linear, $4-5 \times 0.6-1 \mathrm{~mm}$, acute, mid-brown, keeled, wingless, hispid to ciliate hispid, upper bract linear-lanceolate, 3.8-4.6 x 0.4-0.8 mm, acute flat to keeled, transparent light brown, staminate flowers 4 per spicoid, anther linear, $6 \mathrm{~mm}$, stigma branches 2, c. 2 $\mathrm{mm}$ long, whitish; style $4 \mathrm{~mm}$ long. Fruit obovoid, 5-6 x 2-3 mm, apex with extended conical, keeled, base shortly stipitate, exocarp hard, rugose at the upper part and with small tubercles at lower part, brownish at the lower part and become darker toward the apex and apex blackish.

Etymology: This species is named after the Vice Chancellor, Universiti Malaysia Sarawak, Prof. Dato' Dr. Mohamad Kadim Suaidi for his continual support of the biodiversity research in Sarawak.

Vernacular name: Daun Meing (Iban, Sarikei).

Notes: This new species is closely similar to $M$. spadicea, a species described by Uittien from Temburong, Brunei by having strongly 3-ranked leaves and the leaf sheaths being tightly imbricate and distinctly dark chocolate brown (Simpson, 1992). M. kadimiana however, differs from $M$. spadicea by having three spikes terminal capitulum.

\section{CONCLUSION}

The studies of genus Mapania in Borneo and particularly Sarawak has been neglected since the last enumeration by Simpson (1992) until Shabdin et al. (2013a \& 2013b) added two new species and another three recently, with one new record (Miraadila \& Shabdin, 2016) to the list making it 31 species in total. In attaining the important knowledge of this valuable genus, a comprehensive research has been conducted to study the delimitation of the genus in Sarawak. Field excursions have been conducted at various localities from western to eastern part of Sarawak and the observations indicating the presence of tremendous diversity of Mapania in Sarawak. With the discovery of new species $M$. kadimiana, the total number of Mapania species recorded in Sarawak has been increased to 32 species. We believe the number would keep increasing as more remote areas are being explored within Sarawak.

\section{ACKNOWLEDGEMENTS}

We would like to thank Universiti Malaysia Sarawak (UNIMAS) for the facilities and accommodation throughout the fieldtrips. We also thank the Ministry of Higher Education for supporting this project through RAGS Grant: RAGS/STWN10 (1)/1042/2013(09) and Sarawak Forestry Department for granting permits for plant collection: Permit No. NCCD.907.4.4(JLD.11)-63 and Park Permit No. $504 / 2014$.

\section{REFERENCES}

Bridson, D. \& Forman, L. (1992). The herbarium handbook. Revised Edition 
Surrey, UK: Royal Botanic Gardens, Kew.

Govaerts, R., Simpson, A.D., Bruhl, J.J., Egorova, T., Goetghebeur, P. \& Wilson, K.L. (2007). World checklist of Cyperaceae: Sedges. Surrey, UK: Kew Publishing.

Muasya, A.M., Simpson, A.D., Verboom, G.A., Goetghebeur, P., Naczi, R.F.C., Chase, M.W. \& Smets, E. (2009). Phylogeny of Cyperaceae based on DNA sequence data: current progress and future prospects. Botanical Review, 75: 2-21.

Miraadila, M.I. \& Shabdin, Z. (2016). Mapania meekiongii, a new species of Mapania (Cyperaceae) from Sarawak, Malaysia. Folia Malaysiana, 17(1): 61-66.

Shabdin, Z., Culham, A., Simpson, D.A. \& Meekiong, K. (2013a). Mapania sapuniana (Cyperaceae), a new sedge species from Sarawak. Blumea, 58(1): 45-48.
Shabdin, Z., Culham, A., Simpson, D.A. \& Meekiong, K. (2013b). Mapania multiflora, a distinctive new species of Cyperaceae (Mapanioideae) from Borneo. Kew Bulletin, 58(1): 45-48.

Simpson, D.A. (1992). A revision of the genus Mapania. Surrey: Royal Botanic Gardens, Kew.

Simpson, D.A. (1996). New taxa and combinations in Mapania (Cyperaceae) from South America. Kew Bulletin, 51: 729740.

Simpson, D.A., Furness, C.A., Hodkinson, T.R., Muasya, A.M., \& Chase, M.W. (2003). Phylogenetic relationships in Cyperaceae subfamily Mapanioideae inferred from pollen and plastid DNA sequence data. American Journal of Botany, 90(7): 1071108. 